\title{
11 The Court of Justice of the European Union as a law-maker: enhancing integration or acting ultra vires?
}

\author{
Monika Kawczynska
}

\section{The Court of Justice of the European Union as a 'hybrid' court}

Taking into consideration the autonomous nature of the EU legal order, the Court of Justice of the European Union (CJEU) is perceived as a 'hybrid' court, performing different functions as an international court and the domestic court of the European Union.

As an international court the CJEU is acting as a permanent and independent judicial institution set up by international treaties and deciding the cases on the basis of international law with binding effect on the parties. ${ }^{1}$ This is especially apparent in exclusive jurisdiction of the CJEU in disputes between Member States concerning the interpretation or application of the Treaties (Art. 344 TFEU), disputes submitted under a compromise (273 TFEU), and infringement actions adjudicated between Member States (Art. 259 TFEU). It is generally acknowledged that judicial law-making by international courts is creative and that it may have considerable consequences for the regulatory autonomy of states, thus affecting the space for domestic democratic government. ${ }^{2}$

At the same time, the CJEU performs its function as the internal court of the EU and acts in the capacity of a constitutional court, a supreme court, and an administrative court. ${ }^{3}$ The main task entrusted to the Court since its origin is to

1 Tobias Lock, The European Court of Justice and International Courts (Oxford University Press 2015) 7-8.

2 Armin von Bogdandy, Ingo Venzke, 'Beyond Dispute: International Judicial Institutions as Lawmakers' in Armin von Bogdandy, Ingo Venzke (ed.), International Judicial Lawmaking. On Public Authority and Democratic Legitimation in Global Governance (Springer-Verlag Berlin Heidelberg 2012) 4, 7.

3 Koen Lenaerts, 'Some Reflections on the Separation of Powers in the European Community' (1991) Common Market Law Review 28, 32; Vassilios Skouris, The Position of the European Court of Justice in the EU Legal Order and its Relationship with National Constitutional Court (10 November 2019) http://www.us-rs.si/webroot/o-sodiscu/ 3666/contributions/presentation-by-dr-vassilios-skouris-president-of-the-european-cour t-of-justice; Francis Jacobs, 'Is the Court of Justice of the European Communities a Constitutional Court?' in Deirdre Curtin, Daniel O'Keeffe (ed.), Constitutional Adjudication in European Community and National Law (Butterworth Dublin 1992), 25, 25; Anthony Arnull, 'A Constitutional Court for Europe?' (2003-2004) CYELS (Cambridge Yearbook of European Legal Studies) 2; Bo Vesterdorf, 'A Constitutional Court for the EU?' IJCL

DOI: $10.4324 / 9781003022442-12$ 
'ensure that in the interpretation and application of the Treaties the law is observed' (Art. 19 (2) TUE). Performing its functions as a constitutional court, the CJEU is mainly assessing the validity of the acts of general application adopted by the EU institutions also concerning the horizontal and vertical division of competences (Art. 263 TFEU and Art. 267 TFEU), and adjudicates the infringement actions instituted by the Commission against the Member States (Art. 258 TFEU), including observance by the Member States of the Union values: fundamental rights, democracy, and the rule of law. It also gives its opinion as to whether an international agreement is compatible with the Treaties (Art. 218 (11) TFEU). Acting as the supreme court, the CJEU ensures the uniform application of the EU law among the Member States by preliminary rulings concerning the interpretation of the Treaties and acts of the institutions, bodies, offices or agencies of the Union (Art. 267 TFEU). Performing its function as an administrative court, the CJEU ensures the judicial protection of the private parties against illegal administrative actions and omissions of the EU institutions, organs, and bodies (Art. 263 and 265 TFEU), as well as awarding damages for breach of EU law (Art. 340 (2) TFEU).

Exercising its competence, the CJEU has played a key role as 'a motor' or 'a master' of European integration. ${ }^{4}$ Since the 1960s, it has presented a dynamic method of Treaty interpretation and established the foundations of the Union constitutional order. The Court carries out its duties with regard to the values and objectives of the Union enshrined in the Treaty with the view of 'creating an ever closer union among the peoples of Europe' (Art. 1 TEU). Acting within the institutional framework of the Union, the CJEU ensures the consistency, effectiveness, and continuity of the Union policies and actions (Art. 13 (1) TEU). Therefore, it is broadly accepted among the scholars, that the CJEU presents teleological or purposive reasoning, where law is interpreted in the service of an objective that moves European integration forwards. ${ }^{5}$ The Court often refers to 'meta-teleological' arguments, referring to the 'thelos' of the entire legal order,

(International Journal of Constitutional Law) (2006) 4, 607, 607; Eleanor Sharpston, Geert De Baere, 'The Court of Justice as a Constitutional Adjudicator' in Anthony Arnull et al. (ed.) A Constitutional Order of States? Essays in EU Law in Honour of Alan Dashwood (Hart Publishing 2011), 123, 124; Takis Tridimas, 'The European Court of Justice and the Draft Constitution: A Supreme Court for the Union?' in Takis Tridimas, Paolisa Nebbia (eds.) EU Law for the Twenty-First Century: Re-Thinking the New Legal Order, Volume I (Hart Publishing 2004) 113, 114. The CJEU also performs minor functions as a labour court in cases relating to disputes between the Union and its servants and as the court of 'arbitration' having jurisdiction to give judgements pursuant to any arbitration clause contained in a contract concluded by or on behalf of the Union.

4 Thomas Horsley, "Reflections on the role of the Court of Justice as the "motor" of European integration: Legal limits to judicial lawmaking', (2013) Common Market Law Review 50, 931, 934; Dorte Sindbjerg Martinsen, An Ever More Powerful Court? The Political Constraints of Legal Integration in the European Union (Oxford University Press 2015), 23.

5 Gerard Conway, The Limits of Legal Reasoning and the European Court of Justice (Cambridge 2012), 22; Albertina Albors-Llorens, The European Court of Justice, More than a Teleological Court, (1999) Cambridge Yearbook of European Legal Studies 2, 382. 
and the function and consequences of the specific interpretation adopted. In its rulings, the CJEU invokes the effectiveness (effet utille), uniformity, legal certainty, and protection of individual rights as meta-purposes of the EU legal order. ${ }^{6}$

\section{The binding authority of judgements in the EU legal order}

Hans Kelsen distinguished between the work of legislators, which he described as 'creative' and 'positive,' and the work of constitutional judges, which he described as 'negative.' He admitted that the competence to declare legislation unconstitutional is also a law-making, and therefore political, competence. ${ }^{7}$ The CJEU assumes both these roles as 'negative' and 'positive' law-maker.

As negative law-maker, the CJEU has the power to declare an EU act invalid in the context of preliminary ruling procedure enshrined in Article 267 TFEU (declaration of invalidity). Moreover, it can declare the act null and void in the action for annulment specified in Article 263 TFUE initiated by individuals, Member States or the EU institutions (declaration of nullity). ${ }^{8}$ The judgement declaring invalidity or nullity has an erga omnes effect and the contested act may no longer be applied in the EU legal order. As the CJEU underlined in several judgements, the Treaty has established a complete and coherent system of legal remedies and procedures designed to ensure judicial review of the legality of acts of the institutions, and has entrusted such review to the Luxembourg courts. ${ }^{9}$

Positive law-making through adjudication shall be understood as the creation of new legal norms of general application. The creation and development of legal normativity in judicial practice of courts takes place in the context of concrete cases. Judicial decisions settle the particular case between the parties. The court applies relevant norms in the light of the facts and legal interpretations presented to it. At the same time, the court judgement reaches beyond the context of the specific case. ${ }^{10}$

The binding authority of precedent is not an inherent feature of the Union's judicial system. The doctrines of stare decisis and precedent do not formally exist in EU law. ${ }^{11}$ It applies not only to the horizontal relation of judgements at the level of the Court of Justice or the General Court, but also to so-called 'vertical

6 Jan Komarek, 'Legal Reasoning in EU law' in Anthony Arnull, Damian Chalmers (ed.), The Oxford Handbook of European Union Law (Oxford University Press 2017), 46.

7 Hans Kelsen, 'Wesen und Entwicklung der Staatsgerichtsbarkeit'in Veröffentlichungen der Vereinigung der deutschen Staatsrechtslehrer, Heft 5, (Berlin - Leipzig 1929), 56. Alec Stone Sweet, Governing with Judges: Constitutional Politics in Europe (Oxford University Press 2002), 35.

8 Koen Lenaerts, Ignace Maselis, and Kathleen Gutman, EU Procedural Law (Oxford University Press 2014), 457.

9 Case C-50/00 P, of 25 July 2002 (Unión de Pequeños Agricultores), para 40.

10 See von Bogdandy, Venzke (n 2) 12.

11 Daniel Chalmers, Gareth Davies, Giorgio Monti, European Union Law. Cases and Materials (Cambridge University Press 2010), 169-170, Trevor Hartley, The Foundations of European Union Law (Oxford University Press), 71; Marc Jacob, Precedents and Case-Based Reasoning in the European Court of Justice: Unfinished Business (Cambridge University Press 2014) 66. 
precedents' where the General Court is not bound by the judgements of the Court of Justice. ${ }^{12}$ Historically, this can be explained by the fact that the Community was originally founded by States belonging to the family of continental European civil law systems, with the result that the supranational legal order thereby created has similar characteristics. ${ }^{13}$ It is true that the Court of Justice is not bound by its previous decisions, however it is generally acknowledged that in practice it does not often depart from them. ${ }^{14}$ Also the General Court often refers to and follows the decisions of the higher court. In practice, judgments of the CJEU are not treated as precedents, related to and interpreted in the context of a specific case, but rather as a set of normative sentences of general validity. In future cases, such normative sentences are applied in a similar way to legal provisions, not limited by the context of the specific case. In its judicial practice the Court extensively uses so-called 'cluster citations' reproducing sentences or entire paragraphs from its own previous judgements. ${ }^{15}$

The judgments of the CJEU having no broader effects would be unacceptable for the development of the Union legal order and uniform application of the EU law. It is beyond doubt, that the judgements of the CJEU delivered in the preliminary ruling procedure, declaring invalidity of the EU act or its certain provisions, have an erga omnes effect. They are binding in relation to the national court which made the reference, as well as to other national courts outside the specific dispute in the various Member States. ${ }^{16} \mathrm{~A}$ judgement given by the CJEU under Art. 267 TFEU on interpretation of EU law is binding on the national court hearing the case and all courts and tribunals dealing with the case at a later stage of the proceedings. In accordance with the settled case law, an interpretation which the Court gives of a rule of EU law clarifies and defines the meaning and scope of that rule as it must be or ought to have been understood and applied from the time of its coming into force. ${ }^{17}$ Due to declaratory nature of the interpretation given by the Court and necessity of securing uniformity in the application of Union law throughout the Member States, it is widely accepted that also judgements of a preliminary ruling on interpretation extend its binding

12 Kieran Bradley, 'Vertical Precedent at the Court of Justice of the European Union: When Push Comes to Shove' in Kieran Bradley, Noel Travers, Anthony Whelan (ed.), Of Courts and Constitutions Liber Amicorum in Honour of Nial Fenelly (Hart Publishing 2014) 47, 65.

13 Opinion C-331/05 P, of 28 March 2007 (Internationaler Hilfsfonds) para 85; Takis Tridimas, 'Precedent and the Court of Justice: A Jurisprudence of Doubt?' in Julie Dickson and Pavlos Eleftheriadis (ed.), Philosophical Foundations of EU Law (Oxford University Press 2012), 307, 307.

14 Anthony Arnull, 'Owning up to fallibility: Precedent and the Court of Justice', (1993) Common Market Law Review 30, 247, 248.

15 Michael Bobek, 'The Court of Justice of The European Union' in Anthony Arnull, Damian Chalmers (ed.), The Oxford Handbook of European Union Law (Oxford University Press 2015) 153, 170.

16 See Lenaerts, Maselis, Gutman (n 8), 475.

17 Case 61/79, of 27 March 1980 (Denkavit), para 16; case C-453/00, of 13 January 2004 (Kühne \& Heitz), para. 21. 
effect outside the specific case. ${ }^{18}$ This assumption is further strengthened by the doctrine of acte éclairé where the national court may abstain from referring the question under Art. 267 TFEU when the question raised is materially identical with a question which has already been the subject of a preliminary ruling in a similar case. ${ }^{19}$ Such is also the case, when the question raised is substantially the same as a question which has already been the subject of a preliminary ruling in the same national proceedings. ${ }^{20}$ Also Art. 99 of the Rules of Procedure ${ }^{21}$ stipulates that the Court may decide to rule by reasoned order where a question referred for a preliminary ruling is identical to a question on which the Court has already ruled, where the reply to such a question may be clearly deduced from existing case law or where the answer to the question referred for a preliminary ruling admits of no reasonable doubt.

\section{The limits to the judicial law-making of the CJEU. The power of constitutional courts to control the CJEU actions as ultra vires}

As an institution exercising competences of the EU, the CJEU is bound by the principle of conferral (principe d'attribution), laid down in Art. 5 (1) TEU. The second paragraph of the latter provision makes clear that the principle of conferral implies that the EU shall act within the limits of the competences conferred upon it by the Member States, while according to Art. 4 (1) TEU competences not conferred upon the Union in the Treaties remain with the Member States (vertical distribution of competences). Therefore the EU does not dispose of the competence to decide on its own competences (the so-called Kompetenz-Kompetenz). At the same time, according to the Art. 13 (1) TEU, the CJEU shall act within the limits of the powers conferred on it in the Treaties, and in conformity with the procedures, conditions, and objectives set out in them (horizontal distribution of competences). In consequence, the dynamic interpretation of the Union law exercised by the CJEU may not lead to extension of the Union competences, as well as its own judicial powers, beyond the limits designated in the Treaties. However, the analysis of the case law confirms the view that the CJEU tends to have an inherent jurisdiction. It is apparent in cases where the Court is responsible for securing the 'complete system of judicial remedies' within the EU legal order and where strict interpretation of legal provisions may lead to denial of justice (déni de justice). ${ }^{22}$

18 See Lenaerts, Maselis, Gutman (n 8) 244-246; Rene Barents, 'Remedies and Procedures before the EU Courts' (Klwwer Law International 2016), 552; Martin Broberg, Niels Fenger, Preliminary References to the European Court of Justice (Oxford University Press 2014) 444.

19 Cases 28/62 to 30/62, of 27 March 1963 (Da Costa).

20 Case C-337/95, of 4 November 1997 (Parfums Christian Dior), paras 29-30.

21 Rules of Procedure of the Court of Justice of 25 September 2012, OJ L 265, 29.9.2012.

22 Anthony Arnull, 'Does the Court of Justice have Inherent Jurisdiction?' (1990) Common Market Law Review 27, 683, 684. 
The Constitutional Courts of the EU Member States attempt to set boundaries to judicial activism of the CJEU that may transgress the limits of legal interpretation prescribed by the Treaties. The Federal Constitutional Court in the Maastricht judgement, ${ }^{23}$ acknowledged its task to review whether EU legal acts remain within the limited competences of the EU and to declare acts that transgress these borders to be ultra vires and hence inapplicable in Germany (ultra vires review). ${ }^{24}$ The first occasion to assess whether the action of the CJEU amounted to an ultra vires act was the case Honeywell ${ }^{25}$ concerning the debateable Mangold judgment ${ }^{26}$ where the Court found a provision of German labour law to be incompatible with Directive 2000/ $78 / \mathrm{EC}$ and the general principle of non-discrimination on grounds of age. Surprisingly, the Federal Constitutional Court imposed notable limitations on the possibility to declare acts of European institutions inapplicable in the context of an ultra vires control. ${ }^{27}$ It held, that 'ultra vires review by the Federal Constitutional Court can only be considered if a breach of competences on the part of the European bodies is sufficiently qualified. This is contingent on the act of the authority of the European Union being manifestly in breach of competences and the impugned act leading to a structurally significant shift to the detriment of the Member States in the structure of competences.' As concerns the CJEU, 'prior to the acceptance of an ultra vires act, it is to be afforded the opportunity to interpret the Treaties, as well as to rule on the validity and interpretation of the acts in question, in the context of preliminary ruling proceedings according to Article 267 TFEU, insofar as it has not yet clarified the questions which have arisen.' Most recently the Honeywell conditions have been put to the test in the Outright Monetary Transactions reference, ${ }^{28}$ where the Second Senate acknowledged for the first time a so-called 'principal ultra vires objection' based on the right to vote. This decision was based on an ultra vires review and constituted the first preliminary reference in the history of the Federal Constitutional Court. ${ }^{29}$

The strong implications of the principle of conferral were also emphasized by constitutional courts of the Member States in the process of ratification of the Lisbon Treaty. The Federal Constitutional Court in the Lisbon judgement held that

232 BvR 2134/92, 2 BvR 2159/92, of 12 October 1993.

24 Mehrdad Payandeh, 'Constitutional Review of EU law after Honeywell: Contextualizing the Relationship Between the German Constitutional Court and the EU Court of Justice' (2011) Common Market Law Review 48, 9, 9. Mattias Kumm, 'Who is the Final Arbiter of Constitutionality in Europe?' (1999) Common Market Law Review 36, 351, 364.

252 BvR 2661/06, of 6 July 2010.

26 Case C-144/04, of 22 November 2005 (Mangold).

27 Anja Wiesbrock 'The Implications of Mangold for Domestic Legal Systems: The Honeywell Case', (2011) Maastricht Journal of European and Comparative Law 201, 206-207.

28 Case C-62/14, of 16 June 2015 (Gauweiler).

29 Dieter Grimm, Mattias Wendel, Tobias Reinbacher, 'European Constitutionalism and the German Basic Law' in Anneli Albi, Samo Bardutzky (eds.) National Constitutions in European and Global Governance: Democracy, Rights, the Rule of Law (T.M.C. Asser Press 2019) 407, 425. 
the Basic Law does not authorise the German state bodies to transfer sovereign powers in such a way that their exercise can independently establish other competences for the European Union. It prohibits the transfer of competence to decide on its own competence (Kompetenz-Kompetenz) (...) The Federal Constitutional Court has already opened up the way of the ultra vires review for this, which applies where Community and Union institutions transgress the boundaries of their competences. ${ }^{30}$

Similarly the Constitutional Court of the Czech Republic in two judgements concerning the Lisbon Treaty reserved itself a right to review 'whether any act of Union bodies exceeded the powers that the Czech Republic transferred to the European Union,' but only in quite exceptional cases like abandoning the identity of values or exceeding the scope of conferred competences. ${ }^{31}$ In a later case Slovak pensions, ${ }^{32}$ the Czech Constitutional Court for the first time in European history declared the CJEU judgement (in case Landtová), ${ }^{33}$ as ultra vires. It stated, that in that case there were excesses on the part of a European Union body, that a situation occurred in which an act by a European body exceeded the powers that the Czech Republic transferred to the European Union under Art. 10a of the Constitution; this exceeded the scope of the transferred powers, and was ultra vires.'

Correspondingly the Polish Constitutional Tribunal in the Lisbon judgement underlined that, 'the States remain the subjects of the integration process, maintain "the competence of competences," and set a detailed catalogue of inalienable competences that remain under the prohibition of conferral. ${ }^{34}$ The Polish Constitutional Tribunal reserves itself a competence to control EU secondary legislation (normative acts) only where the Constitution explicitly refers to the review of normative acts (i.e. within the framework of a constitutional complaint or questions of law referred by national courts). ${ }^{35}$ By virtue of the limitations imposed on the constitutional complaint procedure, the Tribunal would not be able to examine whether a given act was ultra vires, i.e. whether it was within the scope of competence conferred by Poland on the EU. It may only do so, when an ultra vires action resulted in an infringement of Polish constitutional rights and freedoms. ${ }^{36}$

302 BvE 2/08 of 30 June 2009, paras. 233 and 240.

31 Pl UŚ 19/80, of 26 November 2008; para 120; Pl. UŚ. 29/09, of 3 November 2009, para 150.

32 Pl. UŚ 5/12, of 31 January 2012; Zdeněk Kühn, 'The Czech Republic: From a EuroFriendly Approach of the Constitutional Court to Proclaiming a Court of Justice Judgment Ultra Vires' in Anneli Albi, Samo Bardutzky (eds.) National Constitutions in European and Global Governance: Democracy, Rights, the Rule of Law (T.M.C. Asser Press 2019) 795, 803.

33 Case C-399/09, of 22 June 2011 (Landtová).

34 K $32 / 09$, of 24 November 2010, para. 2.1

35 SK 45/09, of 16 November 2011.

36 Stanisław Biernat, Monika Kawczyńska, 'The Role of the Polish Constitution (Pre2016): Development of a Liberal Democracy in the European and International Context' in Anneli Albi, Samo Bardutzky (eds.) National Constitutions in European 
In legal writings one may find a continuing debate whether the CJEU, through the exercise of its interpretative discretion, contributed to the European integration process or rather improperly overstepped the limits of its judicial function by acting ultra vires. ${ }^{37}$ This chapter will examine the cases where the CJEU has offered dynamic interpretation of the Treaties presenting its activist approach by creating new legal norms of general application. The cases will be divided into four categories depending on the objectives and the underlining motives of the Court approach.

\section{Strengthening the integration}

The most vivid example of judicial law-making occurred in the 1960s while the CJEU declared the principle of supremacy. The EEC Treaty contained no provision dealing with the primacy of Community law over national law. Developing the fundamental principle of EU law in the Costa ${ }^{38}$ case, the Court used a more teleological than textual approach invoking the aims and the spirit of the Treaty. It held that 'the integration into the laws of each Member State of provisions, which derive from the Community, and more generally the terms and the spirit of the Treaty, make it impossible for the States, as a corollary, to accord precedence to a unilateral and subsequent measure over a legal system accepted by them on a basis of reciprocity.' The doctrine of supremacy was founded on the autonomous nature of EU law, resulting from the transfer of competences or limitations of sovereignty by the Member States. According to the Court,

the transfer by the States from their domestic legal system to the Community legal system of the rights and obligations arising under the Treaty carries with it a permanent limitation of their sovereign rights, against which a subsequent unilateral act incompatible with the concept of the Community cannot prevail.

The doctrine of supremacy was further developed in Internationale Handelsgesellschaft, ${ }^{39}$ where the Court pointed out that the provisions of the EU secondary law may not be overridden by rules of national law of any character since it would have an adverse effect on the uniformity and efficacy of the EU law. It held that 'the validity of a Community measure or its effect within a Member State cannot be affected by allegations that it runs counter to either fundamental rights as formulated by the constitution of that state or the principles of its constitutional structure.' While the EU Member States were eager to agree on the primacy of EU law over national statutes and executive acts, the constitutional courts of

and Global Governance: Democracy, Rights, the Rule of Law (T.M.C. Asser Press 2019) $745,756$.

37 Paul Craig, 'The ECJ and the ultra vires action: A conceptual analysis', (2011) Common Market Law Review 48, 395, 395; See Horsley (n 4) 931; See Conway (n 5 ) 17.

38 Case 6/64, of 15 July 1964 (Costa).

39 Case 11/70, of 17 December 1970 (Internationale Handelsgesellschaft). 
several Member States have shown reluctance in accepting unconditional and absolute primacy of Union law over national constitutions. ${ }^{40}$

The first attempt to codify the principle of supremacy occurred at the time of drafting the Constitutional Treaty. The Convention proposed a new Art. I-6 TEU that read as follows: 'The Constitution and law adopted by the institutions of the Union in exercising competences conferred on it shall have primacy over the law of the Member States.' The Article on primacy of Union law was not replicated in the Lisbon Treaty, deliberately depriving the TEU and TFEU of any 'constitutional character. ${ }^{41}$ It was replaced by Declaration 17 Concerning Primacy, recalling the well-settled case law of the CJEU that 'the Treaties and the law adopted by the Union on the basis of the Treaties have primacy over the law of Member States.' The Conference has also decided to attach to the Final Act the Opinion of the Council Legal Service of 22 June 2007, declaring that

primacy of EC law is a cornerstone principle of Community law. According to the Court, this principle is inherent to the specific nature of the European Community. At the time of the first judgment of this established case law (Costa/ENEL) there was no mention of primacy in the treaty. It is still the case today. The fact that the principle of primacy will not be included in the future treaty shall not in any way change the existence of the principle and the existing case-law of the Court of Justice.

The recent research demonstrates that the principle of the primacy of EU law is as absolute and unconditional as it was when it was first developed by the Court in the 1960s and 1970s. The unsuccessful codification in the Constitutional Treaty, the legal relationships between national and European law (constitutional pluralism) as well as the identity clause of Article 4(2) TEU and Article 53 of the Charter, have not essentially altered the principle. ${ }^{42}$

In the 1970s the CJEU developed the doctrine of exclusive implied competence to conclude international agreements by the Community. This is a particularly important legislative activity of the Court, since the doctrine of implied powers deviates from the principle of conferral. At that time the express power to conclude international agreements was provided only in relation to common commercial policy (now Art. 207 TFEU) and association agreements (now Art. 217 TFEU). The judgement in case ERT $A^{43}$ concerned the question of who had the power to conclude European Agreement on Road Transport, since the competence of the Community to enter into international agreements within the

40 See a review of national legal systems in relation to the principle of primacy, Koen Lenaerts, Piet van Nuffel, European Union Law (Sweet \& Maxwell 2011), 772-809.

41 European Council Presidency Conclusions - Brussels, 21/22 June 2007, Annex I, para I.3.

42 Monica Claes, 'The Primacy of EU Law in European and National Law' in Anthony Arnull, Damian Chalmers (eds.), The Oxford Handbook of European Union Law (Oxford University Press 2015) 178, 211.

43 Case 22/70, of 31 March 1971 (ERTA). 


\section{The Court of Justice of the European Union as a law-maker}

sphere of common transport policy was not expressly provided in the Treaty. The Commission argued that since the Council adopted regulation 543/69 on the harmonization of certain social legislation relating to road transport, the Community had the power enter into any agreements with third countries relating to the subject-matter governed by that regulation. The CJEU shared this view and concluded that 'the authority to conclude international agreements arises not only from an express conferment by the Treaty, but may equally flow from other provisions of the Treaty and from measures adopted, within the framework of those provisions, by the community institutions.' In particular when the Community adopts provisions laying down common rules 'the Member States no longer have the right, acting individually or even collectively, to undertake obligations with third countries which affect those rules or alter their scope.'

The doctrine of implied powers was further developed in Opinion $1 / 76 .{ }^{44}$ The subject of the case was the legal competence of the Community to enter into an international agreement establishing a European laying-up fund for inland waterway vessels. The aim of the proposed scheme was to eliminate disturbances arising from surplus carrying capacity for goods by inland waterway in the Rhine and Moselle basins. Such a system was an important factor in the common transport policy, the establishment of which was included in the activities of the Community laid down in article 3 of the EEC Treaty. The Court held that

whenever Community law has created for the institutions of the Community powers within its internal system for the purpose of attaining a specific objective, the Community has authority to enter into the international commitments necessary for the attainment of that objective even in the absence of an express provision in that connection.

The CJEU went further than in ERTA since it declared that the Community should exercise its implied competence to enter into international agreements in all cases in which internal power has already been used in order to adopt measures which come within the attainment of common policies. It is, however, not limited to that eventuality.'

The doctrine of exclusive implied powers of the EU, developed in the cases described above, was codified in the Lisbon Treaty. According to Art. 3 (2) TFEU, the Union shall also have exclusive competence for the conclusion of an international agreement when its conclusion is provided for in a legislative act of the Union or is necessary to enable the Union to exercise its internal competence (Opinion 1/76), or in so far as its conclusion may affect common rules or alter their scope (ERTA).

\section{Safeguarding the powers of Union institutions}

The CJEU has dynamically interpreted legal provisions relating to the protection of the powers of EU institutions, either by recognising competences not provided 
for in the Treaties or shielding the decision-making process against the actions of private parties.

The most vivid example of judicial law making activity of the Court is case Les Verts, ${ }^{45}$ where the members of a political group instituted an action for annulment against two acts adopted by the European Parliament concerning reimbursement of expenditure incurred by participants in the 1984 European elections. At that time the European Parliament was not mentioned as respondent in annulment proceedings. According to former Art. 173 of the Treaty (now Art. 263 TFEU) the Court had only competence to 'review the legality of acts of the Council and the Commission other than recommendations or opinions.' In its judgement the Court held that

an interpretation of article 173 of the Treaty which excluded measures adopted by the European Parliament from those which could be contested by means of an action for annulment would lead to a result contrary both to the spirit of the Treaty as expressed in article 164 [now Art. 19 (1) first subparagraph TUE] and to its scheme, which is to make a direct action available against all measures adopted by the institutions which are intended to have legal effects.

The Court concluded that 'an action for annulment may lie against measures adopted by the European Parliament intended to have legal effects vis-à-vis third parties.' The possibility of bringing action for annulment against acts of the European Parliament, introduced in case Les Verts, was later codified by the Maastricht Treaty as follows 'the Court of Justice shall review the legality of acts adopted jointly by the European Parliament and the Council (...) other than recommendations and opinions, and of acts of the European Parliament intended to produce legal effects vis-à-vis third parties.'

The further development of the European Parliament's position in judicial proceedings took place in case Chernobyl, ${ }^{46}$ concerning the competence of the European Parliament to bring an action for annulment. In 1988 the European Parliament brought an action for annulment against Council Regulation No 3954/87 laying down maximum permitted levels of radioactive contamination of foodstuffs and of feeding stuffs adopted after the nuclear accident that occurred in nuclear power plant in Chernobyl. At that time the competence to bring and action for annulment was provided for in Art. 173 of the Treaty only with regard to Member States, the Council, and the Commission. In Chernobyl the Court famously awarded legal standing to the European Parliament in proceedings for annulment against unequivocal wording of the Treaty. The Court held that

45 Case 294/83, of 23 April 1986 (Les Verts).

46 Case C-70/88, of 22 May 1990 (Chernobyl). 
it would be incompatible with the fundamental interest in the maintenance and observance of the institutional balance (...) to be possible to breach the Parliament's prerogatives without that institution being able, like the other institutions, to have recourse to one of the legal remedies provided for by the Treaties which may be exercised in a certain and effective manner.

At that time the Court was ready to grant a partial locus standi to the Parliament in cases when 'the action seeks only to safeguard its prerogatives and that it is founded only on submissions alleging breach of them.' The admissibility of suits from the European Parliament continued to be quite controversial and it was not until 1992 that the institution brought the first action, the admissibility of which was not challenged by a Member State or the Council. ${ }^{47}$ In response to the Court case law, the Maastricht Treaty introduced a new third paragraph to Art. 173, that read as follows 'The Court shall have jurisdiction under the same conditions in actions brought by the European Parliament and by the ECB for the purpose of protecting their prerogatives.' The full capacity to bring an action for annulment, irrespective of safeguarding the prerogatives, was granted to the European Parliament in 2001 by the Treaty of Nice.

The law-making power of the CJEU was exercised for the purpose of shielding the decision-making process of the $\mathrm{EU}$ institutions against the judicial actions instituted by private parties, particularly in cases challenging the acts of general application, such as regulations or directives.

In famous judgement Plaumann ${ }^{48}$ the CJEU developed the doctrine of 'individual concern' defining the locus standi of the private parties in annulment proceedings. According to former Art. 173 para. 4 of the EC Treaty (now Art. 263 para. 4 TFEU), natural or legal persons were able to institute proceedings against a decision 'which, although in the form of a regulation or a decision addressed to another person, is of direct and individual concern to the former.' The Court held that, 'persons (...) may only claim to be individually concerned if that decision affects them by reason of certain attributes which are peculiar to them or by reason of circumstances in which they are differentiated from all other persons, and by virtue of these factors distinguishes them individually just as in the case of the person addressed.' Due to restrictive interpretation of the individual concern, the possibility of challenging the acts of general application by the individuals was successful only in few cases. ${ }^{49}$ The CJEU attitude attracted considerable criticism, since the restrictive conditions set out in Plaumann were not expressly provided for in the Treaty and were solely the result of judicial interpretation. The Court has interpreted

47 Margaret McCown, 'The European Parliament before the bench: ECJ precedent and EP litigation strategies', (2003) 10 Journal of European Public Policy 974, 977.

48 Case 25/62, of 15 July 1963 (Plaumann).

49 Case C-358/89, of 11 June 1992 (Extramet); case C-309/89, of 18 May 1994 (Codorniu); Anthony Arnull, 'Private Applicants and the Action for Annulment since Codorniu', (2001) 38 Common Market Law Review 7, 7. 
the provision narrowly, while the lack of definition gave the option of adopting a flexible approach as the Court has done in relation to numerous other Treaty concepts. ${ }^{50}$ There was one possibility to open the scope of application of Art. 263 (4) TFUE, where the General Court issued its ruling in case Jégo-Quéré. ${ }^{51}$ The General Court criticized the restrictive interpretation of the Court and held that 'there is no compelling reason to read into the notion of individual concern $(. .$.$) a requirement that an individual applicant seeking to challenge a$ general measure must be differentiated from all others affected by it in the same way as an addressee'. The judges, in order to ensure effective judicial protection proposed a new notion of 'individual concern' of the applicant when 'the measure in question affects his legal position, in a manner which is both definite and immediate, by restricting his rights or by imposing obligations on him'. Regrettably the Court set aside the judgement of the General Court and stated that even in the view of the principle of judicial protection, wide interpretation of Art. 263 (4) TFUE 'cannot have the effect of setting aside the condition in question, expressly laid down in the Treaty. The Community Courts would otherwise go beyond the jurisdiction conferred by the Treaty. ${ }^{52}$ The Treaty of Lisbon has brought some changes to the ability of private applicants to challenge the acts of general application. But even at that time the Court was faced with the duty of binding interpretation of the notion of 'regulatory acts,' mistakenly not mentioned anywhere in the Treaty but in Art. 263 (4) TFUE. The Court interpreted the concept restrictively, covering only non-legislative acts of general application. ${ }^{53}$

The second example of shielding the decision-making powers of the institutions occurred in cases involving action for damages instituted by private parties against the EU. The founders of the Communities left the development of legal conditions applied in cases of non-contractual liability to the judicial activity of the CJEU. Former Art. 215 para. 2 EEC Treaty (now Art. 340 para. 2 TFEU) stipulated that the EU shall make good any damage caused by its institutions or by its servants in the performance of their duties 'in accordance with the general principles common to the laws of the Member States.' In the famous case of Schöppenstedt ${ }^{54}$ the Court held that 'where legislative action involving choices of economic policy is concerned, the Community does not incur non-contractual liability (...) unless a sufficiently flagrant violation of a superior rule of law for the protection of the individual has occurred.' The restrictive interpretation of the conditions related to non-contractual liability of the EU, for the 30 years of applying the so-called 'Schöppenstedt test' granted damages to private parties for legislative acts of the institutions only in 14

50 Albertina Albors-Llorens, 'The Standing of Private Parties to Challenge Community Measures: Has the European Court Missed the Boat?' (2003) 62 The Cambridge Law Journal 72, 74 .

51 Case I-177/01, of 3 May 2002 (Jégo-Quéré).

52 Case C-263/02 P, of 1 April 2004 (Jégo-Quéré).

53 C-583/11 P, of 3 October 2013 (Innit Tapiriit Kanatami).

54 Case 5/71, of 2 December 1971 (Aktien-Zuckerfabrik Schöppenstedt). 


\section{6}

The Court of Justice of the European Union as a law-maker

cases. ${ }^{55}$ The Court applied a less restrictive approach in 2001 in the famous case Bergaderm, ${ }^{56}$ bringing the conditions of non-contractual liability in line with the conditions of the State liability for infringement of EU law. However, taking into consideration the number of successful claims, the approach of the adjudicating panels have not changed much in favour of the private applicants.

\section{Protecting the rights of individuals}

One of the most important concepts of EU law created solely by jurisprudence is the direct effect of EU law. The CJEU first articulated its doctrine in 1960s in the famous judgement Van Gend en Loos. ${ }^{57}$ The Court held that the Community

constitutes a new legal order of international law for the benefit of which the States have limited their sovereign rights, albeit within limited fields, and the subjects of which comprise not only the Member States but also their nationals. (...) Community law not only imposes obligations on individuals but is also intended to confer upon them rights which become part of their legal heritage.

The Court used its teleological approach and concluded that taking into consideration 'the spirit, the general scheme and the wording of the Treaty,' Art. 12 (now Art. 30 TFEU) must be interpreted as producing direct effects and creating individual rights, which national courts must protect. The doctrine of direct effect applies to legal provisions that are sufficiently clear, precise, and unconditional, closely resembling the concept of 'self-executing' norms in international law. Over the years the CJEU has broadened the catalogue of the Treaty provisions that could be invoked by individuals for the protection of their rights, e.g. prohibition of discrimination based on nationality (Art. 18 TFEU), ${ }^{58}$ free movement of EU citizens (Art. 21 TFEU), ${ }^{59}$ prohibition of quantitative restrictions and measures having equivalent effect (Art. 34 and 35 TFEU), ${ }^{60}$ free movement of workers (Art. 45 TFEU), ${ }^{61}$ freedom of establishment (Art. 49 TFEU), ${ }^{62}$ freedom to provide services (Art. 56 TFEU), ${ }^{63}$ free movement of capital (Art. 63 TFEU), ${ }^{64}$ prohibition of concerned practices and abuse of dominant position (Art. 101 and $102 \mathrm{TFEU}^{65}$ or principle of equal pay for male and female workers (Art. 157

55 Monika Kawczyńska, Pozaumowna odpowiedzialność odszkodowawcza Unii Europejskiej (Wolters Kluwer Warszawa 2016), 310.

56 Case C-352/98 P, of 4 July 2000 (Bergaderm).

57 Case 26/62, of 5 February 1963 (van Gend \& Loos).

58 Case 293/83, of 13 February 1985 (Gravier).

59 Case C-413/99, of 17 September 2002 (Baumbast).

60 Case 74/76, of 22 March 1977 (Iannelli \& Volpi).

61 Case C-281/98, of 6 June 2000 (Angonese).

62 Case $2 / 74$, of 21 June 1974 (Reyners).

63 Case 33/74, of 3 December 1974 (van Binsbergen).

64 Cases C-358/93 and C-416/93, of 23 February 1995 (Bordessa).

65 Case $127 / 73$, of 30 January $1974(S A B A M)$. 
TFEU). ${ }^{66}$ In the light of the effective judicial protection of the individuals the Court accepted the possibility of other EU acts having direct effect, such as regulations, ${ }^{67}$ decisions, ${ }^{68}$ directives (restricted to vertical relations), ${ }^{69}$ and international agreements ${ }^{70}$ concluded by the EU.

Another bright example of law-making activity of the CJEU was the concept of the protection of fundamental rights within the Union legal order. The European Communities were originally created as an international organization with an essentially economic scope of action. Neither the Treaty of Paris nor the Treaty of Rome made express reference to the protection of the general principles of law, in particular, fundamental rights. The Constitutional Courts maintained that Community law did not, at that time, ensure a standard of fundamental rights corresponding to their constitutional standards. ${ }^{71}$ It was the CJEU who recognized the existence of general principles as important normative limits on EU institutional activity. ${ }^{72}$ By comparison to the other EU institutions, the Court has been somewhat of a forerunner, taking the first steps towards a fundamental rights system already in 1969 and contributing in many respects to its further development. ${ }^{73}$ In Stauder ${ }^{74}$ the Court already referred to 'fundamental human rights enshrined in the general principles of Community law and protected by the Court.' In Internationale Handelsgesellschaft (see p. 210) it proclaimed that 'respect for fundamental rights forms an integral part of the general principles of law protected by the Court (...). The protection of such rights, whilst inspired by the constitutional traditions common to the member states, must be ensured within the framework of the structure and objectives of the Community.' Later in Nold, ${ }^{75}$ the Court added that, apart from national constitutional traditions, 'international treaties for the protection of human rights, on which the Member States have collaborated or of which they are signatories, can supply guidelines which should be followed within the framework of Community law.' In $R u t i l i{ }^{76}$ the Court made explicit reference to the European Convention of Human Rights, serving as the inspiration for the development of fundamental rights protected within the EU legal order. The principles established in case law were later codified by the Treaty of Maastricht, where Art. F (2) (now Art. 6 (3) TFEU) stipulated that 'The Union

66 Case 43/75, of 8 April 1976 (Defrenne).

67 Case C-253/00, of 17 September 2002 (Muñoz).

68 Case $9 / 70$, of 6 October 1970 ( Grad).

69 Case 41/74, of 4 December 1974 (van Duyn).

70 Case C-265/03, of 12 April 2005 (Simutenkov).

71 Order of the Second Senate 29 May 1974, 2 BvL 52/71 (Solange I), BVerfGE 37, 271; Judgment of Corte Constituzionale of 27 December 1973 (Frontini), 18 Giur. Cost. I 2401.

72 Thomas Horsley, The Court of Justice of the European Union as an Institutional Actor. Judicial Lawmaking and its Limits (Cambridge University Press 2018), 69-70

73 Allan Rosas, 'The European Union and Fundamental Rights/Human Rights: Vanguard or Villain?’ (2017) 7 Adam Mickiewicz University Law Review 7, 20.

74 Case 29/69, of 12 November 1969 (Stauder).

75 Case 4/73, of 14 May 1974 ( Nold).

76 Case 36/75, of 28 October 1975 (Rutili). 
shall respect fundamental rights, as guaranteed by the European Convention for the Protection of Human Rights and Fundamental Freedoms signed in Rome on 4 November 1950 and as they result from the constitutional traditions common to the Member States, as general principles of Community law.'

\section{Increasing the effectiveness of Union law through effective judicial protection}

The CJEU developed the requirement of effectiveness of EU law, including the principle of effective judicial protection, as a general legal principle. In its jurisprudence the Court continuously held that individuals are entitled to effective judicial protection of the rights they derive from the EU legal order, and the right to such protection is one of the general principles of law stemming from the constitutional traditions common to the Member States. ${ }^{77}$ The early case law provided that procedures and remedies for breach of EU law were primarily the matter of the Member States. In Rewe delivered in 1976, the Court invoked the principle of loyal cooperation and held that it is the national courts which are entrusted with ensuring the legal protection which citizens derive from the direct effect of the provisions of Community law. ${ }^{78}$ Accordingly, the CJEU has developed so-called principle of procedural autonomy declaring that, in the absence of EU rules on the matter, it is for the national legal order of each Member State to designate the courts having jurisdiction and determine the procedural rules on condition, however, that those rules are not less favourable than those governing similar domestic situations (principle of equivalence), and that they do not make it excessively difficult or impossible in practice to exercise the rights conferred by EU law (principle of effectiveness).

The most famous example where the Court ruled that EU law requires national courts to provide a specific form of remedy is Francovich, ${ }^{79}$ in which the principle of state liability for breach of EU law was introduced. Although not expressly provided in written law, the Court held that, the principle whereby a State must be liable for loss and damage caused to individuals is 'inherent in the system of the Treaty.' In view of the Court 'the full effectiveness of Community rules would be impaired and the protection of the rights which they grant would be weakened if individuals were unable to obtain redress when their rights are infringed by a breach of Community law for which a Member State can be held responsible.' The basis for the obligation of Member States to make good loss and damage was to be found in the principle of sincere cooperation (now Art. 4 (3) TUE). The Court established a set of conditions sufficient to obtain reparation by the individuals in national courts. The principle of state liability was further developed in Brasserie du Pêcheur, ${ }^{80}$ where the Court clarified the conditions for state liability,

77 Case 222/84, of 15 May 1986 (Johnston); case 222/86, of 15 October 1987 (Heylens).

78 Case 33/76, of the Court of 16 December 1976 (Rewe-Zentral).

79 Case C-6/90 and C-9/90, of 19 November 1991 (Francovich).

80 Cases C-46/93 and C-48/93, of 5 March 1996 (Brasserie du Pêcheur). 
drawing on Art. 215 (2) of the EC Treaty (now Art. 340 (2) TFUE) governing liability for unlawful conduct of the EU institutions. It held that individuals are entitled to reparation, where the rule of EU law breached is intended to confer rights upon them, the breach is sufficiently serious, and there is a direct causal link between the breach and the damage sustained by the individuals. It is beyond doubt that the principle of state liability for breach of EU law is a general principle of EU law, but it has not yet been included in written law. Thus far it is attributed exclusively to the law-making activity of the Court.

In Unión de Pequeños Agricultores, the Court made the recapitulation of the existing case law in the field of judicial protection and held that it is for the Member States to establish a system of legal remedies and procedures which ensure respect for the right to effective judicial protection. ${ }^{81}$ Such a statement was later codified by the Treaty of Lisbon in Art. 19 (1) second subparagraph TUE stipulating that 'Member States shall provide remedies sufficient to ensure effective legal protection in the fields covered by Union law.'

The CJEU guarantees effective judicial protection in fields covered by Union law in domestic legal order, particularly in the Member States departing from democratic standards. Recent constitutional reforms in Poland and Hungary have demonstrated that a lack of respect for the rule of law and for the fundamental values can become a matter of serious concern. ${ }^{82}$ The Member States concerned assert that the organization of the national justice system constitutes a competence reserved exclusively to them, therefore the CJEU transgresses its competences and acts ultra vires. In its jurisprudence, the Court held that although the organization of justice and national procedures falls within the competence of Member States, 'they are required to comply with their obligations deriving from EU law.' In view of the Court 'Member State must, under the second subparagraph of Article 19 (1) TEU, ensure that the bodies which, as courts or tribunals within the meaning of EU law, come within its judicial system in the fields covered by EU law meet the requirements of effective judicial protection. ${ }^{83}$ In fact, the most efficient institution to address systemic threats to the rule of law in countries enforcing illiberal reforms proved to be the CJEU through extensive interpretation of Article 19 (1) TEU.

\section{Conclusion}

Over the years, the CJEU has been acting as an efficient law-maker, placing itself alongside the EU legislature, in order to enhance the European integration. The influence of the Court in the development of EU law has been essential and in some respects unprecedented in the history of legal systems. Through dynamic

81 Case C-50/00 P, of 25 July 2002 (Unión de Pequeños Agricultores).

82 Case C-286/12, 6 November 2012 (Commission v Hungary); case C-619/18, of 24 June 2019 (Commission v Poland).

83 Case C-64/16, of 27 February 2018 (Associação Sindical dos Juizes Portugueses); case C 192/18, of 5 November 2019 (Commission v Poland); joined Cases C-585/18, C-624/ 18 and C-625/18, of 19 November 2019, (Krajowa Rada Sadownictwa). 
interpretation of the Treaties, it has shaped the distinct constitutional features of EU legal order, in both political and economic spheres. ${ }^{84}$ Some of the most important principles of EU law, such as supremacy or direct effect, were developed by the law-making activity of the CJEU, irrespective of the boundaries set by the principle of conferral. It can also be argued that the judiciary has direct influence on European integration, when its considerations and doctrines become incorporated in the policy-making process. ${ }^{85}$ In most instances the Court presented a teleological or purposive approach, making reference to the aims or the spirit of the Treaty. As the basis of its legal reasoning, the Court invoked the autonomy of EU legal order, the uniformity of EU law, effectiveness (effet utille), legal certainty, and effective judicial protection of individuals.

In acting as an efficient law-maker, the Court has not been immune from the criticism of constitutional courts, raising the objections of transgressing the competences provided for in the Treaties and acting ultra vires. The CJEU has been accused of interpreting the Treaty provisions too broadly, taking actually the form of Treaty amendment. This was predominantly evident where the dynamic interpretation of EU law limited the sovereign powers of the Member States. Whereas most constitutional courts underlined the importance of the principle of conferral, only some reserved a right to review whether EU acts transgress these borders to be ultra vires. Despite the initially sharp tone, the Federal Constitutional Court in Honeywell held that ultra vires review can only be considered if a breach of competences on the part of the European bodies is sufficiently qualified. In contrast, the Czech Constitutional Court in Slovak pensions declared for the first time in history the EU Court judgement Landtová as ultra vires. This does not undermine the role of the CJEU as an institutional actor, being the major force in European integration, at the same time ensuring that in the interpretation and application of the Treaties the law is observed.

84 Takis Tridimas, The Court of Justice of the European Union (in:) Robert Schütze, Takis Tridimas (ed.) Oxford Principles of European Union Law. Volume I: The European Union Legal Order (Oxford University Press 2018) 581, 581-582.

85 Fabio Wasserfallen, The Judiciary as Legislator? How the European Court of Justice shapes Policy-Making in the European Union (2010) 17 Journal of European Public Policy 1128, 1129. 